\title{
CCNB1IP1 Gene
}

National Cancer Institute

\section{Source}

National Cancer Institute. CCNB1IP1 Gene. NCI Thesaurus. Code C97372.

This gene plays a role in both ubiquitination and cell cycle progression. 